\title{
DE LA ALIENACIÓN IMITATIVA A LA POTENCIA MIMÉTICA: PLATÓN Y ADORNO, ARISTÓTELES Y BENJAMIN
}

\author{
Castor M. M. Bartolomé Ruiz* \\ doi: 10.11144/Javeriana.uph35-71.aipm
}

\begin{abstract}
RESUMEN
En este ensayo se sostiene la tesis de que la mímesis es una práctica humana atravesada por una condición agonística que la torna paradójica. Las visiones divergentes sobre la mímesis de Platón y Aristóteles, así como las de Adorno y Benjamin, son el reflejo filosófico de la tensión agonística de la mímesis humana. Esta tensión no se resuelve en la verdad exclusiva de una de las posiciones, sino que se mantiene como potencia creadora que permite crear disyuntivas históricas.

Palabras clave: mímesis; Platón; Aristóteles; Adorno; Benjamin; agonismo
\end{abstract}

Unisinos, São Leopoldo, Brasil.

Correo electrónico: castorbartolome@terra.com.br, castor@unisinos.br

Para citar este artículo: Bartolomé Ruiz, C. M. M. (2018). De la alienación imitativa a la potencia mimética: Platón y Adorno, Aristóteles y Benjamin. Universitas Philosophica, 35(71), pp. 145-173. ISSN 0120-5323, ISSN en línea 2346-2426. doi: 10.11144/Javeriana.uph35-71.aipm 


\title{
FROM IMITATIVE ALIENATION TO MIMETIC POTENTIALITY: PLATO AND ADORNO, ARISTOTLE AND BENJAMIN
}

\begin{abstract}
This essay defends that mimesis is an inherently agonistic and paradoxical human practice. The divergent views on mimesis by Plato and Aristotle, as well as by Adorno and Benjamin, are the philosophical manifestation of an agonistic tension of human mimesis that is not resolved in the exclusive truth of one of the positions, but remains as a permanent possibility to create alternative paths in history.

Keywords: mimesis; Plato; Aristotle; Adorno; Benjamin; agonism
\end{abstract}




\section{Introducción}

EL OBJETIVO DE ESTE ENSAYO es analizar algunas posiciones filosóficas sobre la mímesis a fin de mostrar que esta dimensión humana está constituida por una tensión paradójica que no se resuelve anulando ninguno de los polos, sino que la propia tensión paradójica debe ser asumida como constitutiva de la mímesis ${ }^{1}$. Exploramos la hipótesis de que la mímesis no es intrínsecamente perversa, pero tampoco esencialmente buena. Los efectos perversos o las bondades de la mímesis deben ser considerados a partir del análisis crítico de las prácticas miméticas. Sin embargo, la tensión constitutiva de la mímesis dio origen a posiciones filosóficas divergentes y antagónicas que ora la critican, ora la exaltan con vehemencia.

Para caracterizar esta tensión mimética organizamos la exposición de este ensayo en cuatro partes. En un primer momento introduciremos, brevemente, la problemática en el pensamiento prefilosófico y en Platón. Enseguida, analizaremos la perspectiva de Aristóteles sobre la mímesis, destacando los aspectos creadores que el autor percibe en la mímesis. En un tercer momento estudiaremos comparativamente las concepciones de la mímesis de Theodor W. Adorno y Walter Benjamin, en quienes se percibe un hilo de la tensión agonística semejante a la que confrontó las posiciones de Platón y Aristóteles. Concluiremos con una reflexión en torno a la condición agonística de la mímesis humana.

\section{Rastros iniciales de la mímesis humana}

LOS RASTROS DE LA PRÁCTICA MIMÉTICA se confunden con los primeros vestigios de la condición humana, en que la mímesis es captada como actividad imitativa de la naturaleza: se imita el mundo natural para aproximarse o apropiarse de fenómenos que exceden lo humano. En su génesis, la mímesis es una praxis con un alto componente cosmológico (Blumenberg, 1999).

1 Es conveniente recordar que los dramaturgos griegos ya habían percibido la relación entre agốn y múmésis como elementos que integran la actividad lúdica junto con el îlinx (vértigo o desafío) y el ālea (papel del acaso/destino). Véanse Caillois, 1990, y Asman, 1992. 
A lo largo del tiempo vemos procesarse en la mímesis una tensión insoluble entre imitar para asemejarse e imitar distinguiéndose. Esta tensión, que aquí caracterizamos como agonística, es indicio de su potencia paradójica, que se manifiesta al imitar diferenciándose y se diferencia imitando. La condición paradójica que atraviesa la mímesis no es una contradicción que la anula, sino una potencia que abre la acción mimética en varios sentidos y que, como toda acción humana, se realiza en la imprevisibilidad de lo posible. Ejemplo de ello es el mito, que captura el cosmos incomprensible a través de una creación de sentido reflejada en el acto mimético de asemejarse a la naturaleza (Fischer \& Perret, 1988, p. 63-66). En este contexto, el arte desde sus orígenes no se limita a reproducir el cosmos, sino a recrearlo con sentidos nuevos. El arte que imita la naturaleza se asemeja diferenciándose de ella con nuevas creaciones de sentido. La genealogía de las prácticas miméticas nos introduce en los bastidores de las principales categorías filosóficas de la acción humana (Somville, 1979, p. 9). Según Keller, en los círculos pitagóricos la mímesis todavía era practicada en la forma de danza orgiástica con un propósito educativo y terapéutico (Keller, 1954).

La práctica mimética se hunde en la noche de los tiempos. La encontramos actuante en las diferentes imitaciones pictóricas y escultóricas dejadas como rastros por los primeros seres humanos; en ellas camuflarse es imitar la naturaleza con diversas finalidades (Sörbom, 2002). La práctica mimética parece confundirse con la historia de la praxis humana, aunque la reflexión conceptual sobre el sentido de la mímesis es posterior. Encontramos las primeras (re)flexiones sobre el concepto griego mîmos en la magna Grecia presocrática (Sörbom, 1996, p. 16), específicamente en las representaciones teatrales en que los personajes (mîmoi) imitaban diversos elementos (Else, 1958). Las imitaciones eran realizadas en la forma de danza, música o artes escénicas (Wulf, 2008).

La mímesis entra en la filosofía de forma problemática. Si la filosofía se caracteriza por su capacidad de problematizar la realidad, la mímesis representa un modelo de problematización abierta sin (re)solución definida. La mímesis es tematizada ampliamente por los trágicos: Homero, Heródoto, Sófocles, Tucídides, Aristófanes, Eurípides, Esquilo, entre otros, que encuentran en el arte de imitar un tema y un problema (Navarro y Melero, 1981). El gramático Diomedes habla de la imitación de la vida, que contiene tanto lo que está permitido como lo que no está permitido (Keil, 1855/1960, p. 490). Pero son los filósofos 
quienes hacen de la mímesis un problema filosófico. La mímesis penetra en la filosofía bajo la forma de una tensión paradójica cuya (re)solución no se conjuga de un único modo, como veremos a continuación.

Platón lidió vehementemente con la condición paradójica de la mímesis. Este filósofo considera la mímesis, primeramente, como un acto de copiar y toda copia, para Platón, es algo esencialmente inferior a la idea original que imita. Desde esta perspectiva, Platón considera la mímesis una creación (poiésis) inferior que se limita a reproducir las sombras. Platón sustenta una existencia ontológica de las ideas que se desdobla en una epistemología metafísica de las mismas. El mundo de las ideas es lo real, y todo lo que realizamos es su imitación:

Cuando alguno nos anuncie que sabe de un hombre conocedor de todos y cada uno de los oficios, e incluso con más perfección que cualquier otro hombre, convendrá responderle que ha sido víctima de su simpleza y ha caído en el engaño de un encantador o de un imitador, a quien él estimó muy sabio por no ser capaz de distinguir debidamente la ciencia, la ignorancia y la imitación (República, X, 598c-d).

Uno de los argumentos que Platón utiliza en su crítica a los sofistas es que estos son capaces de imitar las cosas reales dando a la imitación una apariencia de realidad. El sofista se caracteriza, para Platón, por un dominio ejemplar de la mímesis. En Sofista, Platón analiza en qué consiste algo que anteriormente no era y que alguien consigue producir (poiésis) como una nueva realidad (219b). La producción de algo que no existía es siempre, para Platón, la imitación de una idea que se quiere reproducir.

Para Platón, la mímesis es una poiésis que imita imperfectamente la realidad; por ello, las obras producidas por la mímesis no pasan de meras sombras de lo real. "Por consiguiente, el arte de la imitación se encuentra alejado de lo verdadero y al parecer realiza tantas cosas por el hecho de que alcanza sólo un poco de cada una y aún este poco es un simple fantasma" (República, X, 598b). El problema de la mímesis en el arte, para Platón, es que representa también una forma de degradación e injusticia, destemplanza e indignidad (Andrade, 2016). La degradación mimética puede afectar al conjunto de la política. Según Platón, algunas modalidades de arte, como la poesía, contribuyen de forma decisiva para degradar el comportamiento ciudadano, porque estimulan la imitación en lugar 
de promover el conocimiento: "por tal motivo no debemos ofrecer entrada al arte en una ciudad con buenas leyes, porque despierta y alimenta el vicio y, dándole fuerzas, destruye también el principio de lo racional" (República, X, 605b).

Para este pensador, el verdadero conocimiento debe superar la mímesis, tiene que anularla para conseguir alcanzar las ideas verdaderas y las formas perfectas. El logos, en su potencia de ver y conocer la verdad, deberá superar la mímesis, pues si se deja contaminar por ella obnubilará su potencialidad de conocer (Murray, 1996). Para Platón la mímesis se manifiesta de múltiples formas, entre ellas la propia narrativa poética, si nos atenemos a la división que el autor presenta en República, III, 392d-394c, donde clasifica la poesía en tres estilos -la narrativa simple, que es representada por el ditiritambo, en el cual el propio poeta habla; la mímesis, representada por la tragedia y la comedia, en las que otros personajes representan lo que el poeta escribió; y lo que Platón denomina narrativa mixta, representada por la poesía épica, en la que el poeta mezcla los dos estilos anteriores-. "El poeta debe renunciar a la poesía como el amante que renuncia a una pasión porque no le hace ningún bien” (República, X, 607e).

Es conocida la postura paradójica de Platón sobre la mímesis (Gali, 1999) y, a pesar de sus severas críticas a la mímesis por imitar la realidad degradándola, reconoce que hay algunos tipos de mímesis que no necesariamente rebajan o falsean la realidad. En Platón, la temática de la mímesis tiene tratamientos diversos y a veces contradictorios, como sustenta Halliwell (2002): "mímesis, en mi opinión, es un caso clásico de un concepto que recibe un tratamiento fluctuante y constantemente revisado en Platón” (p. 38). La posición paradójica de Platón se manifiesta, incluso, en relación con el papel de algunas modalidades de arte, ya que concuerda en que es posible aceptar en la ciudad algunos poetas, siempre y cuando imiten valores éticos verdaderos y eleven la racionalidad. Reconoce así que es posible que el poder persuasivo del arte eleve el espíritu de los jóvenes y los estimule a realizar buenas acciones:

Homero es digno de que se le acoja y se le preste la debida atención en lo que concierne al gobierno y la dirección de los asuntos humanos, hasta el punto de adecuar la vida propia a los preceptos de la poesía [...]. Homero es el más grande y primero de los trágicos. [...] En nuestra ciudad solo convendrá admitir los himnos a los dioses y los elogios a los hombres esclarecidos (República, X, 607a). 
La teoría del conocimiento de Platón exige la función de recordar como actividad central del saber. Conocer, para Platón, es recordar. En ese caso la mímesis reaparece con otra función, que consiste en recordar la idea ontológica. Desde otra perspectiva, recordar la idea es siempre una forma mimética de reconocer el ideal. La idea de bien es inherente a la ontología del ser de todas las ideas; el bien y la belleza se identifican, y se reconocen a través de la rememoración de la idea que hay dentro de cada uno de nosotros.

Otro aspecto de la posición paradójica de Platón se manifiesta en el papel de la mímesis en relación con la propia filosofía. Como fue observado por varios especialistas, Platón recurre a la mímesis para explicar su teoría del conocimiento (Tate, 1928, pp. 16-23; Mazzarelli, 1996, pp. 263 y ss.). Platón reconoce que el pensamiento humano es una constante reproducción del ideal de las cosas, o de la Idea esencial que las cosas tienen. El pensamiento humano sería una copia de la Idea perfecta. Por ello, cuanto más parecida sea la idea humana de la Idea perfecta, más próximo de la verdad estará el conocimiento. Con base en este principio epistemológico, Platón reconoce que la filosofía es una mímesis verdadera. Habría una mímesis verdadera que se distinguiría de la mímesis falsa porque consigue imitar con fidelidad la esencia del ideal. Así pues, la filosofía se caracterizaría, para el autor, por su capacidad de crear la verdadera mímesis, aquella que capta fielmente la imagen de la esencia. Esta distinción es mantenida por Platón en varias obras en que diferencia los tipos de poiésis, considerando la poiésis del filósofo como verdadero conocimiento que capta la imagen de la esencia. En el Sofista sustenta la misma tesis de que la filosofía es la única que realiza la verdadera mímesis (235c). Esta tensión sobre los diversos sentidos de la mímesis no es exclusiva del pensamiento de Platón, sino que adviene de la condición paradójica de la propia mímesis. Analizaremos ahora esa tensión en el pensamiento de Aristóteles.

\section{Aristóteles y la potencia creadora de la mímesis}

El principal discípulo de Platón, Aristóteles, concibió la mímesis con otra perspectiva mucho más positiva y creativa (Veloso, 2004). Inicialmente, Aristóteles aborda la mímesis como un problema filosófico relevante, pero, a diferencia de su maestro, percibe en la mímesis una potencialidad de creación 
que supera la burda imitación de algo. La tensión constitutiva de la mímesis se tornará nítida, una vez más, en la confrontación filosófica del maestro con el discípulo, que no es solo un contraste de posiciones filosóficas, sino también una constatación de que la tensión inherente a la mímesis se refleja en los modos filosóficos de abordarla.

Aristóteles, al confrontarse con la mímesis, opera un giro filosófico hermenéutico sobre un eje doble. Por un lado, no se limita a analizar la mímesis como una mera versión inferior de la poíesis, es decir, como una simple reproducción de algo dado, sino que se pregunta por la potencia de la mímesis en su capacidad de producir y de reproducir algo (Halliwell, 2002, pp. 151-176). El filósofo también disloca el sentido platónico de la mímesis en un segundo eje, conexo con el anterior, al no enfatizar primeramente la cosa que debe ser imitada, sino cómo se imita. Aristóteles analiza la peculiaridad de la mímesis a partir de su capacidad específica para realizar algo y no la restringe a la imitación de un modelo. Para este pensador, la idea de perfección del modelo pasa a un segundo lugar. Lo importante de la mímesis, para Aristóteles, no es el modelo, sino la potencia (dýnămis) mimética y su capacidad de producir y de reproducir (Woodruff, 1992, pp. 73-95). Lo que Aristóteles detecta en la mímesis es la potencia de hacer algo diferente en la semejanza, que, a su vez, lo torna semejante en la diferencia. Esta capacidad mimética requiere una potencia de acción específica, que solo existe como acción porque tiene la potencia de hacer diferente lo semejante. Consecuentemente, para Aristóteles, el modelo no necesariamente es sinónimo de perfección absoluta, y por ello la mímesis no se limita a reproducir una copia imperfecta. De esta forma, el filósofo provoca un giro copernicano en la comprensión de la mímesis con respecto a su maestro, pues el modelo no es el criterio para juzgar la validez o importancia de la acción imitativa, sino que lo esencial de la mímesis es su capacidad de producir algo en relación a un modelo.

Este doble dislocamiento operado por Aristóteles comprende la mímesis como una facultad constitutivamente humana y no un mero tipo de acción inferior que debe ser neutralizado, como ocurría en Platón. Aristóteles analiza la mímesis como una potencia específica inherente a la naturaleza humana ( $m i$ meîsthai), cuya característica principal es la potencia de producir y de reproducir. "El imitar es congénito al hombre, en eso difiere de los otros vivientes, pues, y por imitación aprende sus primeras nociones" (Poética, 1448b). Por ello, lo esencial 
de la mímesis, para Aristóteles, no es la imitación, sino la potencia (dýnămis) de producir algo. Esta potencia, aunque tenga un modelo externo como referencia, es algo propio e independiente del modelo propuesto. La potencia de la mímesis es mucho más que una mera imitación, es también una creación. La potencia de producir o reproducir, aunque sea a partir de un modelo, es en sí misma una potencia de crear algo.

Para Platón, la mímesis está en relación con un paradigma que se propone como ideal. Aquella solo existe como poíesis reproductora o imitativa porque existe el paradigma al que imita. En Platón, esta dualidad confiere a la mímesis un lugar secundario con respecto al paradigma. Para Aristóteles, en cambio, la mímesis está en relación con la mimeîsthai entendida como acción que otorga a la mímesis una dýnămis de hacer algo que por sí mismo es independiente del parádeigma.

Como es sabido, Aristóteles analiza la facultad mimética, principalmente, a partir de la poiésis poética. No es casual que el autor desarrolle esta temática de modo especial en su obra Poética ${ }^{2}$. Tampoco es casual que esta obra haya permanecido como un escrito secundario, casi ignorada por largos períodos, en relación con las otras obras del Estagirita (Black, 1990; Moraux, 2003, pp. 172-183; Veloso, 2002, pp. 93-113).

Una de las características que Aristóteles destaca de la mímesis como potencia productiva es su carácter placentero. El placer de lo agradable (chairein) acompaña al hacer poiético. La mímesis es una poiésis que posibilita a los sujetos el placer de producir algo. Ese placer incorpora la dimensión lúdica a la acción mimética, tornando lo lúdico algo inherente a la mímesis. Para Aristóteles, lo lúdico es constitutivo de la acción creativa de la mímesis. El placer de la mímesis es también una creación que se realiza en la imitación. "Contemplamos con placer las imágenes más exactas de aquellas cosas que miramos con repugnancia (temor), por ejemplo animales feroces y cadáveres" (Poética, 1448b). El placer destacado por Aristóteles en la mímesis contiene, además del carácter lúdico, una fuerte marca estética. El pensador indica que la dimensión estética, disfrutar

2 Recordemos que en la editio princeps de las obras de Aristóteles, publicada en Venecia entre 14951498, la Poética está ausente y solo se publicó junto con la Retórica en 1508, en un corpus de oradores griegos. Véase Irigoin, 1997, p. 171. 
de lo bello, es inherente, también, a la acción mimética. A través de esta doble dimensión del placer lúdico y estético, la mímesis ofrece al ser humano la posibilidad de disfrutar al producir y reproducir algo como semejante y diferente. La asociación entre la acción de la mimèsis, la máthēsis (aprendizaje) y el placer lúdico se encuentra también en su obra Retórica.

Y, como aprender y admirar es placentero, es también necesario que lo sea el que posee las mismas cualidades: por ejemplo, el que constituye una imitación, como la escrita, la escultura, la poesía y en general todas las buenas imitaciones, aunque el objeto imitado no sea agradable; porque no es con ello que se siente placer, sino en pensar que 'este es aquel', de tal forma que como resultado aprendemos alguna cosa (I 11, 1371b5-11).

El placer mimético reside en la capacidad de re-conocer en la obra producida las semejanzas que la identifican y la diferencian del modelo. El placer, según Aristóteles, está vinculado a la capacidad de re-conocer, a la posibilidad de un conocimiento de lo diferente en lo semejante. El placer de la mímesis no estriba en conocer algo como mera copia, sino en la capacidad de reconocer en la copia una diferencia. Por ejemplo, la tragedia imita y produce sentimientos y emociones cuyo placer está en la potencialidad creativa de la obra que reproduce realidades $^{3}$. Lo mismo ocurre con la poesía, cuyo lenguaje imitativo tiene la potencia de suscitar emociones que van más allá de la mera materialidad del lenguaje como copia de algo (Nussbaum, 1995, p. 390).

A diferencia de Platón, que veía en el placer un principio de dispersión y obnubilación del conocimiento verdadero, para Aristóteles el placer agradable y el agrado placentero propio de la mímesis es un estímulo para el mejor aprendizaje, lo que contribuye a adquirir un conocimiento verdadero. La mímesis posibilita aprender por placer y con agrado, estimulando los sujetos a producir a través del disfrute estético.

Aristóteles destaca en la mímesis su peculiar capacidad de correlacionar la dimensión lúdica del placer con el aprendizaje humano (Retórica I 11, 1371b511; Poética, XXIV, 1460a17). El ser humano aprende esencialmente, aunque no

3 En Poética $1147 \mathrm{~b}-10$ Aristóteles se refiere a los mimos de Sofrón y Jenarco, que ya suponen cierto grado de elaboración literaria y que acaso se inspiraran en espectáculos. 
exclusivamente, a través de la mímesis, es decir, imitando a otros. Hay un vínculo conectivo entre mimeîsthai y manthánein por el cual la mímesis se constituye en una facultad inherente al modo humano de conocer y de aprender. El aprendizaje subrayado por Aristóteles en la mímesis tiene que ver con el reconocimiento de las semejanzas a través de las cuales las personas pueden percibir algo como diferente y semejante al mismo tiempo. Ese reconocimiento es una actividad intelectual propia del logos y no una operación mecánica de causa-efecto; ella exige una función lógica a través de la cual la razón identifica las semejanzas por medio de las diferencias. En la mímesis, la semejanza (homoiótes) se aprende a través de la diferencia (Halliwell, 2002, p. 245). La persona que identifica algo como semejante a otra cosa, lo identifica también como diferente de ella. No es lo mismo la cosa identificada que la reproducción que la identifica. Esta diferencia en la identidad es una operación lógica que pone en andamiento las otras operaciones lógicas del aprendizaje.

Aristóteles analiza las potencialidades creativas de la mímesis en la metáfora como figura del lenguaje. Su teoría de la metáfora se desarrolla a través del concepto de semejanza, siendo la relación de semejanza metafórica tanto lógica como estética. La metáfora pone en juego la epistemología del reconocimiento de lo semejante a través de las diferencias. La mímesis es la dimensión que permite esa función lógica y estética de lo que "es percibir bien las semejanzas (tò gàr eû metaphérein tò tó hómoion theōreîn estin)" (Poética, 1459a). Aristóteles, a diferencia de Platón, percibe en la función mimética de la metáfora un aspecto creativo que está más allá de la mera copia de una exterioridad. Esa potencia creativa es inherente al lenguaje producido por la mímesis. En la metáfora se desarrolla la doble dimensión lúdica y estética de la mímesis. Para Aristóteles, la metáfora, operando a través de la mímesis, no se limita a reproducir los atributos de un objeto exterior, sino que produce (crea) una relación lógico-simbólica con el objeto externo. Cuando se dice de alguien que es grande como una torre, veloz como el viento, o blanco como la nieve, no se están estableciendo simplemente comparaciones externas entre el sujeto y el tamaño de una torre, la secuencia temporal de la velocidad del viento o el grado de blancura de la nieve. En la metáfora, según Aristóteles, se crea otro sentido que es inherente al lenguaje que la produce y que no se encuentra en el objeto que sirve de referencia (Poética, 1457b). La comparación metafórica crea un sentido nuevo que no se encuentra en el modelo de 
referencia y que, sin embargo, necesita de ese modelo para que la comparación obtenga el nuevo sentido deseado por la metáfora. En la metáfora, el modelo existe como referencia, pero la imitación que propone es algo nuevo que excede al modelo y que no se encuentra implícito en él.

La metáfora es una operación mimética porque compara algo con una exterioridad, pero la mímesis metafórica produce una conexión entre las dos realidades que excede la mera copia. La relación creada por la metáfora es fruto de la mímesis, aunque supera la simple reproducción de un modelo. Lo singular de la metáfora es que al imitar crea una relación nueva y diferente entre los dos objetos comparados. Es una relación que no existía como tal en ninguno de los elementos comparados, pero que al establecer la imitación metafórica se produce como nueva posibilidad de ser reconocida, que antes no existía. Esa relación metafórica es una creación del lenguaje, es decir, una producción de la dimensión mimética del lenguaje. Lo que caracteriza a la metáfora no es la posibilidad de realizar una copia igual, sino la potencialidad (dýnămis) de producir algo diferente entre semejantes. Una diferencia que los asemeja, una semejanza que los diferencia. Esta potencialidad es propia del lenguaje y de la facultad del ser humano para utilizar el lenguaje de modo mimético.

Para Aristóteles, la mímesis también pone en juego dos posibilidades de ser: la simulación y la emulación. La simulación exhibe una realidad que pretende ser semejante a otra, mientras que la emulación mimética realiza el deseo de aprender según un maestro o de seguir un modelo de ser. Si, por una parte, el actor simula un personaje imitando su modo de ser pero sin asumir esa imitación en su propia vida, por otra, el discípulo que admira al maestro pretende imitarlo emulando su modo de ser para intentar vivir según ese modelo. Esta conjugación mimética de la simulación y la emulación produce identidades que nunca son una pura imitación o copia del modelo. La identificación mimética, para Aristóteles, produce la aproximación de las semejanzas y concomitantemente el distanciamiento de las diferencias. Esta conjugación diversificada de simulación y emulación caracteriza la mímesis como una poiésis con una potencialidad que supera la mera imitación.

Para Elizabeth Belfiore (1992), el papel desempeñado por la mímesis en el pensamiento de Aristóteles está presente en la Poética de un forma muy peculiar, por la analogía que es posible inferir entre la forma poética y los seres 
vivos, especialmente en la relación que se puede establecer entre la poesía y la función de la tragedia. La idea que Aristóteles presenta de la semejanza es central en el nexo emotivo de la tragedia, pero también tiene consecuencias sobre el tipo de sufrimiento de aquellos que se apropian de esta semejanza. Belfiore (1992, pp. 75-79) muestra cómo la compasión y el miedo se despiertan en los espectadores y lectores a través de los crímenes cometidos entre los phíloi. Para la autora, en Aristóteles el protagonista trágico es un "semejante" del espectador y la philía es, a su vez, esencial en la vida humana. Cuando se representa una catástrofe ocurrida sobre enemigos o individuos con los cuales no se tiene un vínculo específico, lo único que se transmite es una idea abstracta del sufrimiento. Pero cuando las tramas representan el sufrimiento entre phíloi, se despierta la compasión y la empatía sobre los semejantes (oikeía) reconocidos como tales en la tragedia. Belfiore (1992) afirma que en Aristóteles "la pérdida de phíloi o el daño cometido contra ellos es, debido a nuestra naturaleza de animales políticos y filiales, lo más terrible y lastimoso que los humanos pueden sufrir" (p. 79) $)^{4}$. Para Aristóteles la compasión y el miedo se despiertan, en primer lugar, porque el sufrimiento del protagonista es inmerecido, pero principalmente porque ese personaje es identificado por los espectadores como un phîlos. Esa identificación con el sufrimiento de un semejante tiene un componente mimético producido por la tragedia en el público. Los procesos de identificación mimética ocurren porque todos los espectadores tienen la experiencia de los lazos de la phĭlía en sus relaciones públicas y privadas, en la polis y en el oikos.

Estas similitudes entre el parentesco biológico y las relaciones basadas en la reciprocidad son fuertemente enfatizadas en la tragedia. En este género, el daño causado a parientes distantes, así como a suplicantes, xenoi y cónyugues tiene una función dramática similar al pathê entre quienes comparten lazos de sangre cercanos, y la aceptación de los forasteros como philoi hacia quienes se tienen obligaciones recíprocas es representada de modo similar

4 "Loss of philoi or harm to them is, because our nature as 'political' and philial animals, the most terrible and pitiable thing humans can suffer." Las traducciones de los fragmentos de Belfiore citados aquí y en adelante son del autor de este artículo. 
al reconocimiento de la identidad de un familiar de sangre que exige actuar como phîlos (Belfiore, 2000, pp. 8-9)'.

Según Belfiore, la trama de la tragedia tiende a asociar mito a mímesis como si fuesen equivalentes, por lo que el enredo de la trama es tanto el proceso de imitación como el producto imitado. La tragedia, para desarrollar la mímesis, se vale de las palabras poéticas que producen cierta conexión entre los hechos y las acciones que representan. Tales nexos, que también son constitutivos del mŷthos, deben provocar las emociones de placer y dolor en el público. El hecho de que la tragedia cause placer no significa que se deje de sentir dolor (Belfiore, 1985, p. 349).

Elizabeth Belfiore (1992) sustenta que la estructura de la trama trágica, considerada en sí misma, es suficiente para despertar la compasión y el miedo en el público. Según la autora, cuando se describe la trama como alma de la tragedia, para Aristóteles, no es un símil vacío, sino que es una realidad que refleja la propia ontología de los seres vivientes. Esa similitud es semejante a la forma como Aristóteles sustenta en su obra De Anima que el alma es a la vez el origen y la forma de un cuerpo físico con potencial para la vida. Belfiore (1992), siguiendo a Aristóteles, considera que la trama es el alma de la tragedia y también de la poética, pues Aristóteles utiliza esta analogía para retratar la tragedia como "un acto que imita a la naturaleza” (p. 56). Belfiore caracteriza la poética como un proceso semejante al que ocurre en los cuerpos vivos, ya que ambos están dirigidos a un fin específico que es el bien de su existencia. Para Aristóteles, el alma no es simplemente la forma del cuerpo, sino que es su finalidad (télos) y también su causa eficiente. El mismo modelo ontológico se aplica a la tragedia, pues así como es el alma la que dirige un ser vivo para su finalidad interna, que es la vida, también la trama es esencial para la conducción de la tragedia a su finalidad específica (télos), que es despertar la compasión y el miedo. La autora señala que también hay algunas diferencias entre ambos ámbitos, sobre todo en la relación entre el proceso y el resultado de cada uno.

5 "These similarities between biological kinship and relationships based on reciprocity are strongly emphasized in tragedy. In this genre, harm to distant kin, and to suppliants, xenoi, and spouses has a dramatic function similar to pathê among close blood kin, and the acceptance of outsiders as philoi toward whom one has reciprocal obligations is represented as similar to the recognition of the identity of a blood relative that involves acting as a philos." 
En la naturaleza, el proceso por el cual se desarrolla un ser vivo es diferente del producto, el ser vivo completo. Esto también se aplica al arte de la construcción de viviendas [...]. En el caso de la tragedia, sin embargo, la trama es tanto el proceso de imitación como el producto producido por la imitación (Belfiore, 1992, p. 55) ${ }^{6}$.

Sin la trama, una tragedia no puede ser trágica, pero hay otra diferencia con la ontología de los seres vivos, pues el alma de los seres vivos es también su causa eficiente, en cuanto para una trama poética se necesita el poeta para componerla.

Para Belfiore, en la tragedia entran en juego tanto las dimensiones cognitivas como las físicas. Por ejemplo, el llanto inicial de la representación de un acontecimiento trágico es una respuesta fisiológica natural a los sentimientos de compasión, que son inducidos por la trama. De igual modo, el aspecto cognitivo de la compasión sentida ante un personaje representado es una copia que imita el escenario humano real donde ocurren eventos dolorosos. Esa compasión es una respuesta emocional que aumenta en intensidad cuando se reconocen eventos inevitables, como los de Edipo, que forman parte de la condición humana.

La compasión supone el lamento y el llanto [...] pues la compasión, al igual que el temor, involucra reacciones fisiológicas dolorosas (llorar) que de algún modo son necesarias para la producción de placer estético [...] Estas reacciones, sin embargo, no son involuntarias ni automáticas [...] La compasión, en el pensamiento griego, es una emoción esencialmente humana, que depende de la conciencia de pertenecer a un mundo humano común $[. .$.$] muchas veces senti-$ mos compasión por personas que se encuentran en situaciones completamente desesperadas... Lloramos al ver a Edipo con los ojos cegados porque vemos lo que nos parece ser un hombre en dolor y en llanto... Finalmente, en la medida en que nos estremecemos y lloramos en la tragedia en cuanto personas que lloran, nos percatamos de que la tragedia es una imitación de un suceso digno de

6 "In nature, the process by means of which a living thing develops is different from the product, the completed living thing. This is also true of the craft of house building [...]. In the case of tragedy, however, the plot is both the process of imitating and the product produced by imitating." 
compasión y temor: que esta trama es uma imitación de aquel evento (Belfiore, 1985, pp. 359-360) ${ }^{7}$.

4. Contrastes con algunas visiones contemporáneas de la mímesis: T. Adorno y W. Benjamin

LA TEMÁTICA DE LA MÍMESIS atraviesa la historia de la filosofía desembocando en nuestra contemporaneidad con posiciones controvertidas de diversos autores. En esas controversias se muestra la tensión paradójica inherente a la función mimética que recorre las diversas posiciones filosóficas. A modo de ejemplos paradigmáticos de actualización de la mímesis, presentamos sintéticamente las posiciones de T. Adorno y W. Benjamin. No es objetivo de este ensayo, por falta de espacio, explorar exhaustivamente las posiciones y argumentaciones de cada autor, sino mostrar las tesis principales de estos pensadores contemporáneos sobre la mímesis a fin de percibir en ellas la tensión paradójica originaria de la mímesis desde la filosofía antigua.

Adorno y Horkheimer (2006) abordan la problemática de la mímesis en su obra La dialéctica de la ilustración, primeramente en el análisis que realizan sobre la Odisea. En esta obra, los autores enfocan la mímesis con una crítica similar a la de Platón. Adorno y Horkheimer apoyan su visión crítica de la mímesis en las interpretaciones de Sigmund Freud y de algunos etnólogos como Marcel Mauss. Para estos autores, la mímesis es un modo pasivo de imitar la realidad (Früchtl, 1986, p. 13). Siguiendo los estudios de Caillois (2002), Adorno y Horkheimer relacionan el paradigma de la mímesis con el mimetismo animal que, en caso de peligro, se esconde camuflándose miméticamente con el medio en que se encuentra. El camuflaje mimético es, para estos autores, la manera a través de la

7 "Pity involves wailing and weeping [...] for pity, like fear, involves involuntary, painful physiological reactions (weeping) that are necessary in some way to the production of aesthetic pleasure [...] These reactions, however, are not involuntary and automatic [...] Pity, in Greek thought, is an essentially human emotion, dependent on an awareness of the common human lot [...] we often feel pity for people in completely hopeless situations [...] We weep while viewing Oedipus with his eyes put out because we see what appears to us to be a man in pain and weeping [...] Finally, because we shudder and weep at the tragedy qua people weeping, we realise that it is an imitation of a pitiable and fearful event: that this plot is an imitation of that event." 
cual el sujeto deja de ser lo que es para mimetizarse como idéntico al entorno. Al mimetizarse, los sujetos, animales o personas, pretenden desaparecer, pasar desapercibidos, anularse como sujetos para no ser percibidos por un peligro potencial. El mimetismo esconde la singularidad del sujeto en la homogeneidad del ambiente. Es, así, la actitud que anula la individualidad para fundirse con las semejanzas comunes formando un ambiente igual, indiferenciado, donde todo se identifica como unidad sin singularidad y como totalidad semejante. Cualquier forma de totalidad impera sobre los individuos como un totalitarismo indiferenciado. Este es el aspecto crítico de la mímesis que Adorno y Horkheimer pretenden subrayar, en especial sus desdoblamientos ético-políticos.

Estos dos autores reconocen que existe una experiencia inicial o primitiva de la mímesis por la cual se provoca una identificación con el objeto y a través de ella se procura una catarsis ético-pedagógica. Esta experiencia de mímesis primitiva promueve el desarrollo ontológico del individuo en su relación con el todo.

En el lugar de la adaptación orgánica al otro, del mimetismo propiamente dicho, la civilización ha introducido primero, en la fase mágica, el uso regulado de la mímesis y finalmente, en la fase histórica, la práctica racional, el trabajo. La mímesis incontrolada es proscrita (Adorno \& Horkheimer, 1998, p. 224).

Estos pensadores subrayan otro aspecto crítico de la mímesis, aquel que la "civilización" ha conseguido implementar como medio de subyugación de las diferencias. En este caso, la mímesis se torna en una imitación heterónoma que asimila el sujeto al todo de la civilización.

La severidad con la que en el curso de los milenios los dominadores han prohibido a su propia prole y a las masas sometidas la recaída en las formas miméticas de vida, empezando por la prohibición religiosa de las imágenes, y pasando or el rechazo social de actores y gitanos, hasta la pedagogía que enseña a los niños a no comportarrse como tales, es el presupuesto de la civilización (Adorno \& Horkheimer, 1998, p. 224).

En el límite de la civilización, para estos autores, "toda distracción, incluso toda entrega, tiene algo de mimético" (Adorno \& Horkheimer, 1998, p. 224). El yo del sujeto se constituye cuando resiste a esta tendencia asimiladora. La constitución del sujeto en cuanto tal se realiza en la medida que es capaz de pasar de una mímesis reflectora (ser un mero reflejo mimético del todo) a una reflexión 
controlada. La mímesis civilizatoria sustituye la asimilación con la naturaleza, propia de la mímesis primitiva, por la identificación cognitiva en el concepto. Esa identificación mimética del concepto produce la dilución de las diferencias en una identidad única. El uso instrumental de la mímesis promueve el surgimiento de lo idéntico. La identidad asimilada a la unidad idéntica del todo "es siempre la [constelación] del terror” (Adorno \& Horkheimer, 1998, 224). Para Adorno y Horkheimer, la masificación del mimetismo promueve la normalización de los trazos idénticos y el olvido de las diferencias. El olvido es la marca del mimetismo totalizante. "En el modo burgués de producción la indestructible herencia mimética de toda praxis es condenada al olvido" (Adorno \& Horkheimer, 1998, p. 225). Y los hombres obcecados con la civilización no se dan cuenta de los trazos miméticos que les atraviesan, solo perciben un cierto sentimiento de extrañeza cuando se confrontan con algunos gestos o comportamientos de otros.

En esta perspectiva expuesta por Adorno y Horkheimer, el mimetismo anula la distancia entre sujeto y medio, borra las diferencias entre los sujetos transformando las diferencias en una especie de totalidad indiferenciada donde los individuos desparecen como tales. El factor predominante en este tipo de mímesis es el miedo. En este caso, la mímesis opera anulando la subjetividad y negando al propio sujeto que se asimila a un todo a través de la disimulación que lo camufla. Para Adorno y Horkheimer, el papel de la civilización, representado paradójicamente en la figura de Ulises, supera la función pasiva de la mímesis primitiva. "Los comportamientos mimético, mítico y metafísico aparecieron sucesivamente como eras superadas" (Adorno \& Horkheimer, 1998, p. 83). La civilización crea el logos y se produce como algo diferenciado de los bárbaros, que no tienen logos. El logos de la civilización permite diferenciarse de la mera naturaleza, escapando de la barbarie mimética de la naturaleza a que están sometidos los ignorantes. Ulises representa así la victoria de una cierta racionalidad estratégica sobre la mera mímesis natural.

Sin embargo, para Adorno y Horkheimer, la superación de la mímesis natural por el logos civilizado es aparente, pues la civilización se construye encima de la reproducción mimética, transformada por ella en conquista de la naturaleza. Dominar y conquistar para reproducir será la máxima civilizatoria del logos occidental. Con ello, la civilización construye una segunda forma de mímesis que reproduce "civilizadamente" la mímesis natural. Esta segunda mímesis se 
construye sobre la base del recalque de la primera. "La fórmula de la astucia de Odiseo consiste en que el espíritu separado, instrumental, en la medida en que dócilmente se pliega a la naturaleza da a esta lo que le perteneces y de este modo la" (Adorno \& Horkheimer, 1998, p. 108).

Para Adorno, una de las manifestaciones perversas del mimetismo civilizado fue el fascismo antisemita. En el capítulo sobre el antisemitismo, de la obra $L a$ dialéctica de la ilustración, analiza cómo los fenómenos contemporáneos de masas, específicamente el nazismo y el antisemitismo, tienen en su base una función mimética en la que los sujetos se anulan y son anulados en sus diferencias para remitirse a una identidad totalitaria que proyecta al otro, en este caso los judíos, como una exterioridad perversa. "En el lugar de la adecuación física a la naturaleza entre el 'reconocmiento... en el concepto' (Kant, $\mathrm{KrV}$ ), la asunción de lo diverso bajo lo idéntico" (Adorno \& Horkheimer, 1998, p. 224).

El fascismo y su antisemitismo reflejan el triunfo del mimetismo segundo, o mimetismo recalcado, sobre el mimetismo natural. Es una mímesis perversa que muestra el lado obscuro de toda mímesis. Adorno y Horkheimer retoman la crítica de Platón a la mímesis y amplían el análisis de sus consecuencias políticas, entre ellas los perversos efectos de alienación de masas, algo muy específico de las sociedades contemporáneas.

En sus obras finales, Adorno propone una cierta reconsideración de esta crítica negativa de la mímesis (Sinha, 2000, pp. 145-159). En su obra La dialéctica negativa (1986) y especialmente en la obra Teoría estética (1982), Adorno propone otros abordajes de la mímesis, sin invalidar las duras críticas formuladas en La dialéctica de la ilustración (Cahn, 1984, pp. 38 y ss.). En su última obra, Teoría estética, analiza el arte como el último refugio del comportamiento mimético, una mímesis redimida que conseguiría huir tanto de la magia como de la regresión (Gagnebin, 1993, p. 84)

Otro autor contemporáneo que tematizó la mímesis como dimensión importante de la acción humana fue Walter Benjamin. Aunque Benjamin era compañero de Adorno y Horkheimer en el Instituto de Investigación Social y con ellos mantuvo intensos diálogos y aproximaciones, su visión de la mímesis es diferente. Las diferencias de W. Benjamin y T. Adorno sobre la mímesis, salvando las distancias, parecen una reproducción mimética de las posturas de Platón y Aristóteles. 
Benjamin estudia el papel de la mímesis en relación con el lenguaje humano. Sus tesis son expuestas inicialmente en dos ensayos de 1916, "Sobre el lenguaje general y sobre el lenguaje de los humanos" (2001), y de 1921, "La tarea del traductor" (1997), complementados con otros dos escritos de 1933, "Doctrina de lo semejante" (2007) y "Sobre la facultad mimética” (1996). A semejanza de Aristóteles, Benjamin distingue en la actividad mimética humana un aspecto de reconocimiento imitativo de un modelo externo, pero también percibe un segundo aspecto de producción de semejanzas. El autor piensa que "el conocimiento de los ámbitos de lo 'semejante' tiene un significado fundamental para esclarecer grandes sectores del saber oculto" (Benjamin, 2007, p. 208). Pero, para Benjamin, lo importante no es comprender las semejanzas, sino los procesos que las producen. Aunque en la naturaleza también se encuentran semejanzas -"no hay más que pensar en el mimetismo” (Benjamin, 2007, p. 208)-, para Benjamin, el ser humano es el único que tiene la capacidad de producir las semejanzas. Esa producción de semejanzas es una potencialidad del lenguaje humano que consigue establecer una relación entre semejanzas extra-sensibles.

Para Benjamin, los juegos infantiles son la práctica humana donde se despliega de forma más plena la actividad mimética. Así como Aristóteles, Benjamin destaca la vinculación de la mímesis con el placer, el aprendizaje y el conocimiento. El ser humano produce semejanzas porque es capaz de imitar la realidad que vive. Pero, paradójicamente, las semejanzas que produce no son iguales ni permanecen las mismas. Hay que diferenciar entre semejanza e identidad. La identidad iguala, la semejanza diferencia. Benjamin, como Aristóteles, entiende que la mímesis es una facultad humana y no un mero tipo de acción inferior. A través de la mímesis aprendemos y también producimos las semejanzas. La mímesis es el puente que consigue establecer vínculos entre el lenguaje y el conocimiento.

Para Benjamin, ni las fuerzas miméticas ni las 'cosas' a mimetizar permanecen iguales en el transcurso del tiempo. La potencia mimética, como todas las facultades humanas, es también producida, y modificada, por la praxis histórica de los sujetos. "Con el paso de los siglos la fuerza mimética (y, más adelante, con ella, la percepción mimética, ha desaparecido en ciertos campos, tal vez para derramarse en otros distintos" (Benjamin, 2007, p. 209). Para Benjamin, la mímesis ha cambiado de forma, pero la potencia mimética se mantiene en el ser humano. En las actuales sociedades tecnológicas y científicas, el principal espacio 
de la mímesis se encuentra en el lenguaje. Sin embargo, Benjamin se niega a reconocer el origen del lenguaje en la mera mímesis onomatopéyica o gráfica de las palabras. Esta concepción del lenguaje es reduccionista, así como el significado de la mímesis en la constitución de las semejanzas. Para Benjamin, lo específico de la facultad mimética es su capacidad de producir las semejanzas. Como decíamos, para el autor, la semejanza no es mera copia del modelo, sino una versión interpretativa del mismo. La semejanza producida por la mímesis no es una imitación sensible, sino la creación de algo extrasensible a partir de elementos sensibles. El lenguaje es el principal espacio donde la facultad mimética produce las semejanzas extrasensibles: "la semejanza no sensorial es aquello que funda la conexión no sólo entre lo dicho y lo que quería decirse, sino también entre lo escrito y lo que quería decirse, así como entre lo dicho y lo que se ha escrito. Y en cada caso de una manera completamente nueva, originaria e inderivable" (Benjamin, 2007, p. 211). Para el autor, el modus operandi del lenguaje es estrictamente mimético en la medida en que, por ejemplo, entre la palabra escrita y la hablada predomina una semejanza que no está dada por lo que hay de similar entre ellas, sino por la semejanza que el sujeto crea entre los sonidos y las letras o signos. Esa semejanza obedece a una nueva forma de mímesis que imita sonidos en relación con signos y viceversa.

Hay que suponer que la facultad mimética que resulta expresada de esta manera en la actividad del escritor tuvo en todo caso la mayor importancia para lo que era el acto de escribir en los tiempos remotos en que surgió la escritura. Así, se ha convertido la escritura (al lado del lenguaje) en un archivo no sensorial de semejanzas, de correspondencias que no son sensoriales (Benjamin, 2007, p. 211).

Benjamin bucea más hondo en la problemática inquiriendo si la dimensión mimética que produce las semejanzas en el lenguaje se desenvuelve aisladamente de la comprensión semiótica de la misma. Su respuesta es negativa. Para el autor, todos los elementos miméticos del lenguaje solo pueden venir a la luz sobre otro fondo constitutivo del lenguaje, externo a la mímesis, que es la dimensión semiótica o comunicativa de todo lenguaje. La posibilidad de comprender sentidos en los signos o en las palabras no es algo específico de la capacidad mimética; el modo de hacerlo sí. Benjamin utiliza la comparación entre el astrólogo y los 
videntes que leen el designio de las vidas en los astros o en las entrañas de los animales, y el niño que descifra en las letras el significado de las palabras. Son dos estratos de lecturas diferentes, el primero utiliza claramente la dimensión mimética para interpretar en los astros o en las vísceras de los animales señales de un lenguaje escrito en la naturaleza. La pregunta que se hace Benjamin es si este tipo de mímesis, ya desaparecida en las sociedades científicas, no habría emigrado para la capacidad interpretativa del niño en su lectura descifradora de palabras y textos. En este caso, el lenguaje sería "el uso supremo de la facultad mimética" (Benjamin, 2007, p. 212). La mímesis se habría transformado en un médium en que las facultades primitivas que percibían lo semejante por la naturaleza no se relacionan más de forma directa con las cosas, como sucedía con los adivinos o videntes, sino que penetró en el modo de relacionar el lenguaje y de comprender la escritura. El ritmo y la velocidad exigidas por la lectura y escritura son inseparables del proceso mimético; a través de ellas el espíritu humano participa del segmento temporal en que las semejanzas irrumpen dentro del flujo de las cosas, siempre transitoriamente, para después desaparecer. Toda lectura crítica vive esta experiencia de la temporalidad relativa a la comprensión de las cosas que lee, los sentidos de la lectura no se muestran evidentes como algo sensible que se capta de inmediato, sino que se deshilan en una temporalidad exigente, de un tiempo propio para que el lector cree el sentido de lo que lee. Esa temporalidad sería una versión contemporánea de la mímesis en la producción de las semejanzas y ella es condición para que el lector no se vaya "con las manos vacías" (Benjamin, 2007, p. 213).

Aunque la interpretación de la mímesis de Benjamin se aproxima mucho a la de Aristóteles, la diferencia entre ambos es que Benjamin entiende la historicidad como una dimensión inherente a la mímesis, hasta el punto de que, para el autor, la propia facultad mimética cambia a lo largo de la historia. Según Benjamin, la mímesis, de algún modo, es un producto histórico. No cambian solo los contenidos mimetizados, sino el modo de mimetizar. Eso hace que la producción de semejanzas no sea una mera reproducción de lo mismo a lo largo de la historia, sino que en cada momento de la historia se producen semejanzas diferentes de lo mismo. Cada momento histórico es capaz de ver algo diferente en lo mismo, provocando la producción de semejanzas diferentes cada vez. Las 
posibilidades de similitudes son indefinidas y cada sujeto y momento histórico produce sus interpretaciones de lo mismo como algo diferente.

Para Benjamin, la actividad mimética era muy evidente en la antigüedad, ya que se imitaba la naturaleza en todas sus vertientes. En la modernidad se han eliminado muchas de las mímesis antiguas, pero la actividad mimética no ha sido eliminada por la razón; se ha condensado en la propia actividad racional, especialmente en el lenguaje y en la escritura. Así, la facultad mimética del ser humano contiene la doble posibilidad de reconocer y producir las semejanzas. Para ello, Benjamin forja el concepto de semejanza no sensible (unsinnliche Ähnlichkeit) y define al lenguaje como el último grado de capacidad mimética del ser humano (Gagnebin, 2005, p. 97). La racionalidad no anuló ni provocó la decadencia de la actividad mimética, sino que la transformó internalizándola en sus modos racionales de actuar; eso ocurre de modo ejemplar en el lenguaje y sus formas. El lenguaje, para Benjamin, no es creado por el mero arbitrio de la voluntad ni se origina de forma convencional, sino que representa la reproducción de semejanzas. Reproducir semejanzas en el lenguaje no significa imitar identidades, sino producir diferencias a partir de una referencia. La actividad mimética es una mediación simbólica que no se limita a imitar lo mismo, sino a reproducir lo semejante en su diferencia. Para Benjamin, el modelo comparativo de la transformación filogenética del lenguaje se encuentra en el cambio ontogenético que ocurre en el niño. La transformación que el niño realiza para apropiarse del lenguaje a través de la imitación es un reflejo del proceso histórico del propio lenguaje.

Benjamin entiende que la mímesis no produce identidades de lo igual, sino semejanzas de lo diferente. Así como la metáfora en Aristóteles, la mímesis es una actividad productiva de novedad a través de la cual se produce algo que excede el modelo imitado. La mímesis, para Benjamin, es una dimensión esencial del ser humano que le permite aprender y producir, y producir aprendiendo.

\section{Conclusiones}

LOS ESTUDIOS QUE PRESENTAMOS anteriormente sobre la condición agonística de la mímesis se aproximan a la percepción de Gebauer y Wulf (1995) cuando afirman que el mundo empírico no representa nada en sí mismo, ya que, para ser 
comprendido, es necesaria la creación mimética de lo que ellos denominan "un segundo mundo" que crea sentidos para el primer mundo. Así lo entienden también Jean-Paul Fischer et Jean Baptiste Perret cuando en su artículo sobre "La mimesis sociale : l'approche historique de Gunter Gebauer et Chistoph Wulf" destacan la afirmación de Gebauer y Wulf según la cual "la actividad mimética no se limita a dos mundos: en realidad es transversal a varios mundos, a lo largo de una cadena de relaciones entre-mundos" (Gebauer \& Wulf, 1995, citado en Fischer \& Perret, 1998, p. 63) ${ }^{8}$. No obstante, las posiciones hasta aquí esbozadas sobre la mímesis, lejos de pretender agotar su sentido, indican la irreparable apertura de sentido que atraviesa su modo de ser. La conjugación de las posiciones antagónicas expuestas anteriormente nos permite percibir que la mímesis está atravesada por una doble dimensión agonística y paradójica que la torna susceptible de varias posibilidades de ser sin que ninguna de ellas pueda ser conclusiva.

El agốn habita la mímesis abriéndola a posibilidades diferentes en contextos propios. Es posible utilizar la mímesis como práctica que anula las diferencias, como indicaba Adorno. En este caso, la mímesis trae las personas adentro de la caverna, proyectando las sombras producidas exteriormente como verdades reales. Los sujetos, presos de la mímesis alienante, vacían su capacidad crítica y se asimilan disimuladamente en una totalidad que los absorbe, anulándolos. La crítica de Platón y Adorno a la dimensión alienante de la mímesis es pertinente, ya que la dimensión agonística de la mímesis posibilita este tipo de uso.

Sin embargo, la misma condición agonística no permite que la mímesis se encierre conclusivamente en la definición de una mera práctica alienante, totalizadora o anuladora de las diferencias. El agốn que habita la mímesis posibilita producir otras formas prácticas de acción diferentes de la alienación. La mímesis puede ser, también, una práctica creativa que, a través de la imitación, crea la diferencia de aquello que imita. La mímesis, en este caso, se torna una dimensión creativa del ser humano, como indicaban Aristóteles y Benjamin. La mímesis es también una dimensión inherente al aprendizaje humano, que incluye algún tipo o grado de apropiación imitativa de aquello que se aprende. El aprendizaje incorpora conocimientos y habilidades acumuladas históricamente y con ello

$8 \ll$ [...] l'activité mimétique ne se limite pas à deux mondes : elle est en fait transversale à plusieurs mondes, le long d'une chaîne de relation inter-mondes. » 
catapulta al sujeto en poco tiempo a través de siglos de duras y difíciles conquistas humanas. El aprendizaje incorpora una dimensión mimética, sin que con ello la mímesis se reduzca a mera reproducción de lo igual. Aprender es apropiarse creativamente del modelo. La mímesis, en este caso, opera como una facultad creativa que se apropia imitando e imita creando. Esta potencialidad mimética de reproducir creativamente no impide reconocer que la misma mímesis es susceptible de reducción instrumental a mera imitación de modelos dados.

La mímesis, al afirmar las dos posiciones antagónicas sobre una misma dimensión humana, parece regresarnos al clásico debate filosófico sobre la contradicción y la aporía. Afirmar la condición agonística de la mímesis, lejos de provocar una aporía filosófica, evita que caigamos en el falso dilema dualista de tener que catalogar como verdaderas unas posiciones y falsas las otras, pudiendo afirmar la verdad de ambas de forma diferente. No es posible confrontar las posiciones de Platón y Adorno con las de Aristóteles y Benjamin como si fuese un debate entre la verdad y la mentira, lo bueno y lo malo de la mímesis. Lo verdadero y falso, lo bueno y lo malo de la acción mimética tienen que ser analizados en el modo como la mímesis es utilizada en cada contexto histórico. La mímesis no es buena o mala por naturaleza, así como no produce la verdad o la mentira por esencia. Ella es una facultad que, como toda acción humana, está traspasada por la tensión agonística que la torna paradójica en sus posibilidades de uso. Se puede afirmar que las posiciones diferentes y divergentes de los autores son igualmente verdaderas, en la medida en que analizan aspectos concretos a través de los cuales la dimensión agonística de la mímesis se presenta históricamente. Lo que en la mímesis trasluce es una potencialidad abierta de ser diferente en cada contexto o modo de uso.

El punto crítico de la mímesis no se encuentra en la disyuntiva de alguna de sus posibilidades históricas, sino en su convergencia crítica abierta por la tensión agonística que la atraviesa. Esta perspectiva nos permite comprender la naturaleza histórica de la mímesis, sin que por ello su sentido se agote en la mera descripción sociológica de sus modos de ser. La especificidad de la mímesis se manifiesta en el eje tenso y paradójico que le permite constituirse históricamente como potencialidad de la acción humana que se cristaliza de diversos modos y hasta en contradictorios tipos de acción. No hay una verdad única de la mímesis, o una mímesis verdadera y otra falsa, ya que la condición paradójica le permite 
expresarse en algunos casos como imitación alienante de sombras y en otros como imitación creativa de semejanzas. La verdad de la mímesis no está en una de las disyuntivas, sino en la posibilidad de crear disyuntivas o de crearse históricamente como una forma histórica diferente. La condición paradójica del ser humano hace posible que la mímesis se exprese como convergencia tensional capaz de asimilar al otro miméticamente o, también, como práctica que le permite distinguirse de él a través de la diferenciación mimética.

\section{Referencias}

Adorno, T. W. (1982). Teoria estética. (Trad. Artur Mourão). São Paulo: Martins Fontes.

Adorno, T. W. (1986). Dialéctica negativa. Madrid: Taurus.

Adorno, T., \& Horkheimer, M. (1998). Dialéctica de la Ilustración. Fragmentos filosóficos. (Introducción, traducción y notas de J. J. Sánchez). Madrid: Trotta. Andrade, A. C. (2016). Mímesis: a fonte, o tampo e o véu. Manuscrito inédito facilitado por el autor.

Aristóteles. (1974). Poética. (Trad. V. García Yebra). Madrid: Gredos.

Aristóteles. (1994). Retórica. (Trad. Q. Racionero). Madrid: Gredos.

Asman, C. L. (1992). Theatre and Agon/Agon and Theatre: Walter Benjamin and Florens Christian Rang. MLN, 107(3), 606-624.

Belfiore, E. (1985). Pleasure, Tragedy and Aristotelian Psychology. The Classical Quartely, 35(2), 349-361.

Belfiore, E. (1992). Tragic Pleasures: Aristotle on Plot and Emotion. Princeton: Princeton University Press.

Belfiore, E. (2000). Murder Among Friends. Violation of Philia in Greek Tragedy. New York-Oxford: Oxford University Press.

Benjamin, W. (1996). Gesammelte Briefe (Vol. II). 1919-1924. Ch. Gödde \& E. H. Lonitz. (Eds.). Frankfurt a.M.: Suhrkamp.

Benjamin, W. (1997). Gesammelte Briefe (Vol. III). 1925-1930. Ch. Gödde \& E. H. Lonitz. (Eds.). Frankfurt a.M.: Suhrkamp.

Benjamin, W. (2001). Sobre el lenguaje en general y sobre el lenguaje de los humanos. En: Iluminaciones IV. Para una crítica de la violencia y otros ensayos. (Trad. R. Blatt) (pp. 59-74). Madrid: Taurus. 
Benjamin, W. (2007). Doctrina de lo semejante. En: Obras (Libro II, vol. 2) (Trad. J. Navarro Pérez) (pp. 208-213). Madrid: Abada.

Black, D. L. (1990). Logic and Aristotle's Rhetoric and Poetics in Medieval Arabic Philosophy. Leiden: Brill.

Blumenberg, H. (1999). "Nachahmung der Natur". Zur Vorgeschichte der Idee des schöpferischen Menschen. En: Wirklichkeiten in denen wir leben: Aufsätze und eine Rede (pp. 266-283). Suttgart: Reclam,

Caillois. R. (1990). Les jeux et les hommes. Lisboa: Cotovia.

Caillois, R. (2002). Mimétisme et psychasténie légendaire. En: Le mythe et l'homme (pp. 50-75). Paris: Gallimard.

Cahn, M. (1984). Subversive Mimesis: Theodore W. Adorno and the Modern Impasse of Critique. En: M. Spariosu. (Ed.). Mimesis in Contemporary Theory: An Interdisciplinary Approach (Vol. I) (pp. 27-64). The Literary and Philosophical Debate. Philadelphia: John Benjamin's Publishing Company. Else, G. F. (1958). Imitation in the Fith Century. Classical philology, LIII(2), 73-90.

Fischer, J.-P., \& Perret, J.-B. (1988). La mimesis sociale : l'aproche historique de Gunter Gebauer et Christoph Wulf. Hermès, La Revue (22), 63-66.

Früchtl, J. (1986). Mimesis. Konstellation eines Zentralbegriffs bei Adorno. Würzburg: Königshausen \& Neumann.

Gagnebin, J. M. (1993). Do conceito de mímesis no pensamento de Adorno e Benjamin. Perspectivas, 16, 67-86.

Gagnebin, J. M. (2005). Sete aulas sobre linguagem, memória e história. (2.a ed). Rio de Janeiro: Imago.

Gali, N. (1999). Poesía silenciosa, pintura que habla. De Simónides a Platón. La invención del territorio artístico. Barcelona: El Acantilado.

Gebauer, G., \& Wulf, C. (1995). Mimesis. Culture, Art, Society. Berkeley: University of California Press.

Halliwell, S. (2002). The Aesthetics of Mimesis: Ancient Texts \& Modern Problems. Princeton: Princeton University Press.

Irigoin, J. (1997). Tradition et critique des textes grecs. Paris: Les Belles Lettres.

Keil, H. (Ed.). (1960 [1855]). Grammatici latini (Vol. I). Flavii Sosipatri Charisii Artis Grammaticae Libri V, Diomedis Artis Grammaticae Libri III, 
Ex Charisii Arte Grammatica Excerpta. Hildesheim: Olms [edición original de Teubner].

Keller, H. (1954). Dei mimesis in der Antique. Diss: Bern.

Mazzarelli, C. (1996). Presentazione, traduzione e note. Sofista. Platone. Tutti gli scritti a cura di Giovani Reali (pp. 262-314). Milano: Rusconi.

Moraux, P. (2003). Les listes anciennes des ouvrages d'Aristote. Louvain : Éditions Universitaires de Louvain.

Murray, P. (Ed.). (1996). Plato on Poetry. New York: Cambridge University Press.

Navarro, J. L., \& Melero, A. (1981). Introducción. De los Mimiambos y de los Fragmentos mímicos. En: Herodas, \& Paternio de Nicea. Miambos. Fragmentos mimicos. Sufrimientos de amor. Madrid: Gredos.

Nussbaum, M. (1995). The Fragility of Goodness. Luck and Ethics in Greek Tragedy and Philosophy. Cambridge: Cambridge University Press.

Platón. (1950). Oeuvres complètes. (Trad. L. Robin). Paris: Bibliothèque de la Pléiade.

Platón. (1966). República. Obras completas. (Trad. J. A. Miguez). Madrid: Aguilar.

Platón. (1996). Tutti gli scritti. G. Reali. (Ed.). Milano: Rusconi.

Sinha, A. (2000) Adorno on Mimesis in Aesthetic Theory. En: H. Briel, \& A. Kramer. (Eds.). In Practice. Adorno, Critical Theory and Cutural Studies (pp. 145-159). Berlin: Peter Lang.

Somville, P. (1979). Mimesis et art contemporain. Paris: Vrin.

Sörbom, G. (1996). Mimesis and Art. Studies in the Origin and Early Development of an Aesthetic Vocabulary. Uppsala: Svenska Bokförlaget Bonniers.

Sörbom, G. (2002). The Classical Concept of Mimesis. En: P. Smith, \& C. Wilde. (Eds.). A Companion to Art Theory (pp. 19-28). Oxford: Blackwell.

Tate, J. (1928). 'Imitatio' in Plato's Republic. The Classical Quarterly 22, pp. 16-23.

Veloso, C. W. (2002). La Poetica: scienza produttiva o logica?. En: D. Lanza. (Ed.). La Poetica di Aristotele e la sua storia (pp. 93-113). Pisa: ETSUniversità degli Studi di Pavia.

Veloso, C. W. (2004). Aristóteles mimético. São Paulo: Discurso Editorial. 
Woodruff, P. (1992). Aristotle on Mimesis. En: A. O. Rorty. (Ed.). Essays on Aristotle's Poetics. Princeton: Princeton University Press.

Wulf, Ch. (2008). Mimetic Learning. Designs for Learning, 1(1), pp. 56-67. 